\title{
Phytochemical Screening and Antimicrobial Activity of Roselle (Hibiscus sabdariffa L.) Flower Extract Against Aeromonas hydrophila
}

\author{
Sitti Khairul Bariyyah ${ }^{* 1}$, Arief Prajitno ${ }^{2}$, Ating Yuniarti² \\ 1* Master Program of Aquaculture, Faculty of Fisheries and Marine Science, University of Brawijaya, Malang, Indonesia \\ ${ }^{2}$ Faculty of Fisheries and Marine Science, University of Brawijaya, Malang, Indonesia
}

\begin{abstract}
Medicinal plants as an antimicrobial agent may provide an alternative way to replace the use of antibiotics to control disease agents in aquaculture. Roselle flowers (Hibiscus sabdariffa L.) has been used in many sectors as a source of functional food, natural coloring agents as well as antimicrobial agents. The objectives of this study were to evaluate the phytochemical compound in methanolic extract of roselle flower and their antimicrobial activity against Aeromonas hydrophila. The phytochemical composition of roselle flower was evaluated using phytochemical screening and FTIR. While the antimicrobial activity was performed by using the disc diffusion agar and co-culture with $A$. hydrophila. The results of phytochemical screening confirmed the presence of alkaloids, flavonoids, saponins, steroids, triterpenoids, and tannins. The results of FTIR revealed that Roselle flower extract had the main phenolic compounds. The result of disc diffusion and co-culture method indicated that the roselle flower extract had antibacterial activity against $A$. hydrophila. This antibacterial activity depended on the concentration applied.
\end{abstract}

Keywords: antibiotics, Co-culture, Disk diffusion, flavonoid, Hibiscus sp.

\section{INTRODUCTION}

Aeromonas hydrophila is a common bacteria in freshwater habitats throughout the world [1]. It cause diseases both in human and animals including fish and shrimp [2]. Bacterial infections with Aeromonas hydrophila as a disease agent have resulted in heavy losses up to $80 \%$ and economic loss to fish farmers [3,4].

Usually, many farmers have used antibiotics to control this disease. However, antibiotics have become the major factor for the emergence and dissemination of multi-drug-resistant strains of several groups of microorganisms [5]. An effort to overcome the negative effects of antibiotic application is the use of medicinal plants. Plants are rich in a wide variety of secondary metabolites such as tannins, alkaloids, and flavonoids, which have been found in vitro to have antimicrobial properties [6]. There have been several reports on the antimicrobial activity of different herbal extracts [7-9].

Hibiscus sabdariffa L., well-known as roselle, is a common flower plant grown worldwide. More than 300 species of hibiscus can be found around the world [10]. Roselle have been used in many sectors as a source of functional food, natural coloring and antimicrobial agents [1113]. Several studies found that roselle flower have significant antimicrobial activities against

\footnotetext{
* Correspondence address: Sitti Khairul Bariyyah

Email : rheea.tayang@gmail.com

Address : University of Brawijaya, Veteran Malang, 65145.
}

several strain of bacteria such as Micrococcus luteus, Serratia mascences, Staphylococcus aureus, Staphylococcus epidermidis, Salmonella enterica, Pseudomonas aeruginosa, Klebsiella pneumonia, Proteus vulgaris, Escherichia coli, and Bacillus cereus $[14,15]$. Yet, no studies found to reveal the antimicrobial activities against $A$. hydrophila as a bacterial disease agent in aquaculture. Therefore, this study was intended to evaluate the phytochemical screening and antimicrobial activity of Roselle flower extract on A. hydrophila indigenous aquatic.

\section{MATERIAL AND METHODS}

Preparation of Roselle flower Extract

Roselle flower ( $H$. sabdariffa L.) was originated from house of medicinal plant, Batu, East Java. The flowers were air-dried and grounded into fine powder using an electric blender. Extraction process was performed based on the methods of [16] with some modification. A hundred (100) g of air-dried powder was mixed with $500 \mathrm{ml}$ of methanol solvent and then was kept for $24 \mathrm{~h}$. Later, it filtered through Whatman filter paper (no. 42) and centrifuged at $5.000 \mathrm{~g}$ for $10 \mathrm{~min}$. The extract was evaporated using a rotary evaporator at $40^{\circ} \mathrm{C}$.

\section{Phytochemical Composition and FTIR of Roselle Flower Extract}

Phytochemical screening was carried out to confirm the presence of alkaloids, flavonoids, saponins, triterpenoids, steroids, and tannins using the standard method [17]. FTIR analysis was also conducted to elucidate the 
phytochemical composition of roselle flower extract based on standard methods [18]. Roselle flower extract (1 mg) was homogenously mixed with $100 \mathrm{mg} \mathrm{KBr}$ and pressed in to pellet. FTIR spectra were recorded in the range $4000-400 \mathrm{~cm}$ 1 in FTIR spectroscopy (OPUS 4.2, Karlsruhe, Germany).

\section{Bacterial preparation}

Isolate of Aeromonas hydrophila was originated from Jepara Brackishwater Aquaculture Center. This bacterium was kept in Trypticase Soy Agar (TSA) media at $4^{\circ} \mathrm{C}$ and subcultured Trypticase Soy Broth (TSB) in overnight before use.

\section{Antimicrobial assay}

Concentration of Roselle flower extract used in this study were $0,1,10,100,500$ and 1,000 $\mathrm{mg}^{-1}$ which diluted in $10 \%$ DMSO. Antimicrobial assay was carried out using modified disc diffusion method and co-culture method. The modified disc diffusion method was performed based on [19]. The overnight bacterial suspension was adjusted to the concentration of $10^{7}$ CFU. $\mathrm{mL}^{-1}$ and seeded $(0.1 \mathrm{~mL})$ on Muller Hinton Agar (MHA) plate. Each treatment $(5 \mu \mathrm{L})$ of Roselle flower extract was applied in to MHA plate. A positive control antibiotic (Chloramphenicol $5 \mathrm{mg} \cdot \mathrm{mL}^{-1}$ ) and a negative control (without extract) was used in this assay. MHA plates were incubated at $37^{\circ} \mathrm{C}$ for 24 hours. Antimicrobial activities was evaluated by measuring the inhibition zone. The co-culture method was performed based on [20]. In $100 \mathrm{~mL}$ $\mathrm{TSB}, A$. hydropila $(1 \mathrm{~mL})$ was inoculated with an initial bacterial count of $10^{7}$ CFU. $\mathrm{mL}^{-1}$. The flower extract was added in to the flask at the varied concentration above. Those co-culture flasks were incubated at $37^{\circ} \mathrm{C}$ on shaker (120 rpm) for 24 hours. The $A$. hydrophila was enumerated by using the standard plate method. All treatments were performed in triplicates.

\section{RESULT AND DISCUSSION \\ Phytochemical Composition}

The phytochemical analysis was performed to confirm the presence of alkaloids, flavonoids, saponins, steroids, triterpenoids and tannins in the extract of roselle flower. The results of phytochemical analysis were given in the Table 1. The results showed that all the compound tested were found in roselle flower extracted with methanol solvents. Results of this phytochemical analysis was also supported by the earlier studies [21]. They reported that the flower of roselle contained group of alkaloids, flavonoids, saponins, steroids, triterpenoids and tannins. Other plants that have antimicrobial activities were also had these compounds [22-24].

Table 1. The Phytochemical Analysis of Roselle Flower Extract

\begin{tabular}{cc}
\hline Metabolites & Results \\
\hline Alkaloids & + \\
(Dragendroff) & \\
Alkaloids & + \\
(Mayer) & \\
Flavonoids & ++ \\
Saponins & + \\
Steroids & + \\
Triterpenoids & + \\
Tannins & + \\
\hline
\end{tabular}

Notes: $+++=$ strong, $++=$ medium,$+=$ weak intensity [25]

\section{FTIR Analysis Results}

The spectrum of FTIR was designed to identify the functional group of bioactive compound. This assignment was confirmed based on the peaks value in the IR radioation region. The FT-IR spectrum of roselle flower extract is presented in Fig. 1, while the spectra is interpreted in Table 2. The results indicated that there were various functional groups present in the roselle flower extract.

Table 2. Assignment of FT-IR Absorption Bands in the Roselle Flower Extract

\begin{tabular}{ccl}
\hline $\begin{array}{c}\text { Absorption } \\
\text { frequency }\left(\mathbf{c m}^{-1}\right)\end{array}$ & Bond & $\begin{array}{c}\text { Tentative } \\
\text { assignment }\end{array}$ \\
\hline $3,419.71$ & $\mathrm{O}-\mathrm{H}$ & Alcohol, phenol \\
2928.91 & $\mathrm{C}-\mathrm{H}$ & Alkanes \\
1743.03 & $\mathrm{C}=\mathrm{O}$ & Aldehydes \\
$1,630.18$ & $\mathrm{C}=\mathrm{C}$ & Alkenes \\
$1,384.12$ & $\mathrm{C}-\mathrm{H}$ aliphatic & Alkanes \\
$1,228.37$ & $\mathrm{C}-\mathrm{O}$ & Carboxylic acid \\
$1,065.59$ & $\mathrm{C}-\mathrm{O}$ & Carboxylic acid \\
523.34 & $\mathrm{C}-\mathrm{H}$ & Aromatics \\
\hline
\end{tabular}

The result of FTIR analysis confirmed the presence of phenol, alkanes, aldehydes, carboxylic acid, and aromatics. Allegation that the results of the isolate are phenolic compounds where the benzene group binds to one $\mathrm{OH}$ group with a wide and sharp inclination with absorption at the wave number area $3419.71 \mathrm{~cm}^{-1}$ and $1384.12 \mathrm{~cm}^{-1}$. And reinforced functional groups $\mathrm{OH}, \mathrm{C}=\mathrm{C}, \mathrm{C}=\mathrm{O}, \mathrm{C}-\mathrm{H}$ aromatic [26-28]. Based on the results of phytochemical screening analysis and FTIR analysis, it can be linked that flavonoids and positive tannins contained in roselle flower extract are derivatives of phenol $[29,30]$. According to previous study [31], phenol derivatives contained in plants have antimicrobial activity. 


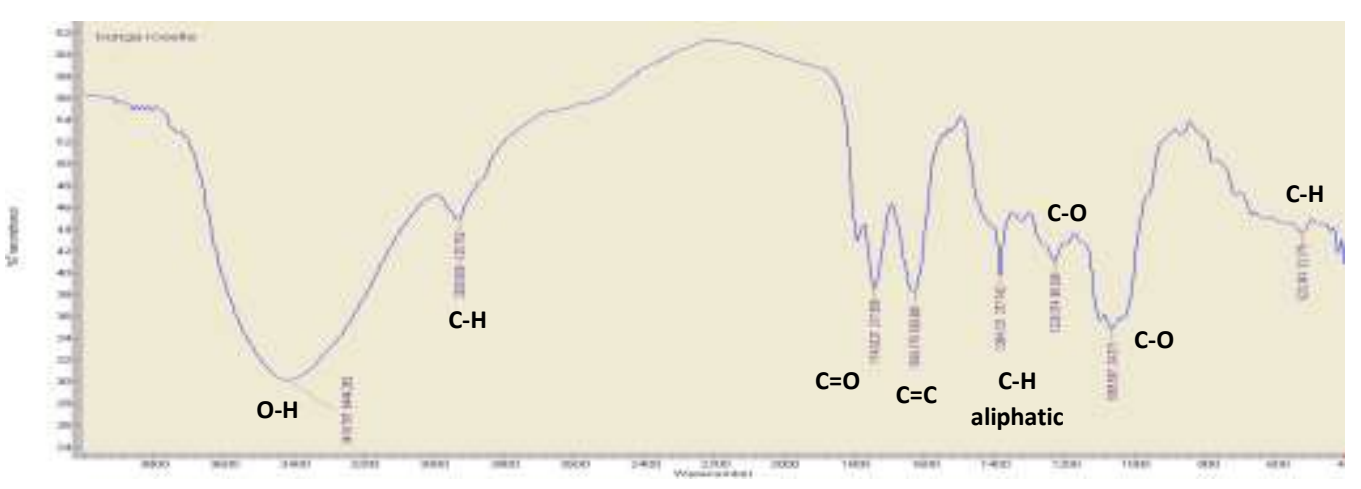

Figure 1. FTIR Test Results of Rosella Flower Extract (H. sabdariffa L.).

\section{Antimicrobial Assay}

The results of antimicrobial assay of $H$. sabdariffa L. provide valuable information and highlight the potential value of this plant in aquaculture drug development. Classification was made based on the width of the clear zone formed. The results of the antimicrobial assay of the methanolic extract of $H$. sabdariffa $L$. against A. hydrophila can be seen in Table 3.

Table 3. Antimicrobial Testing of Roselle Flower Extract against $A$. hydrophila by Using Disc Diffusion

\begin{tabular}{ccc}
\multicolumn{3}{c}{ against $A$. hydrophila by Using Disc Diffusion } \\
\hline $\begin{array}{c}\text { Concentration of } \\
\text { Roselle flower extract } \\
\left.\text { (mg. } \mathbf{L}^{-1}\right)\end{array}$ & $\begin{array}{c}\text { Clear Zone } \\
\text { Diameter } \\
(\mathbf{m m})\end{array}$ & $\begin{array}{c}\text { Inhibitory } \\
\text { Responses }\end{array}$ \\
\hline $\begin{array}{c}\text { Control (-) } \\
1\end{array}$ & $0.00 \pm 0.0^{\mathrm{a}}$ & Weak \\
10 & $0.00 \pm 0.0^{\mathrm{a}}$ & Weak \\
100 & $2.19 \pm 0.0^{\mathrm{b}}$ & Weak \\
500 & $7.12 \pm 0.8^{\mathrm{c}}$ & Medium \\
1000 & $15.02 \pm 0.5^{\mathrm{d}}$ & Strong \\
Control (+) & $18.37 \pm 0.3^{\mathrm{e}}$ & Strong \\
\hline
\end{tabular}

Description: $\leq 5 \mathrm{~mm}=$ weak, $5-10 \mathrm{~mm}=$ medium, $10-20 \mathrm{~mm}=$ strong [32]

Table 4. Co-Culture Test Result

\begin{tabular}{ccc}
\hline No & $\begin{array}{c}\text { Concentration of } \\
\text { Roselle flower extract } \\
\left(\mathbf{m g . L}^{-1}\right)\end{array}$ & $\begin{array}{c}\text { Bacterial count } \\
\text { (CFU. } \mathbf{~ m L}^{-1} \text { ) }\end{array}$ \\
\hline 1 & Control (-) & $2.70 \mathrm{E} 18$ \\
2 & 1 & $2.66 \mathrm{E} 18$ \\
3 & 10 & $1.85 \mathrm{E} 14$ \\
4 & 100 & $1.08 \mathrm{E} 11$ \\
5 & 500 & $8.6 . \mathrm{E} 09$ \\
6 & 1000 & $5.3 . \mathrm{E08}$ \\
7 & Control (+) & 0 \\
\hline
\end{tabular}

The result of disc diffusion and co-culture method indicated that the roselle flower extract had an antimicrobial activity against $A$. hydrophila (Table 4). Some studies also revealed the antibacterial activities of Roselle extract against some bacteria such as Streptococcus mutans [33], Campylobacter jejuni, C. coli, C. fetus [34]. The antibacterial activities detected in this study were concentration-dependent. The higher the concentration of Roselle flower extract, the higher the antibacterial detected against $A$. hydrophila. It can be seen from Table 3 that the concentration of roselle flower extract which categorized withs strong ability to inhibit the growth of $A$. hydrophila was started from 500 $\mathrm{mg} . \mathrm{L}^{-1}$. In line with that finding, the results of coculture assay showed that the significant reduction of $A$. hydrophila count was also from the same concentration. The antimicrobial activity was influenced by several factors such as the concentration of extract, the content of antibacterial compounds, the diffusion power of extracts and the type of bacteria [35].

The ability of Roselle flower extract to inhibit the growth of $A$. hydrophila depend on their bioactive compound. The main compound of Roselle are organic acids, anthocyanins, polysaccarides and flavonoids [36]. Based on the results of the phytochemical screening test and FTIR analysis in this study, it was found that Roselle flower extract had the main phenolic compounds such as flavonoids, tannins. These phenolic compounds have the ability to form certain complex structures on bacterial cell walls. Furthermore, with the number of hydroxyl groups present in the phenolic ring there will be an increase in hydroxylation, and with increased hydroxylation, antimicrobial activity will increase [37].

Other compounds which were also found in Roselle methanol extract are alkaloids, saponins, steroids, and triterpenoids. Those compounds have also antimicrobial activities by damaging the structure of cell walls and changing the permeability of cell cytoplasmic membranes [38], [39]. Changes and damage to the cytoplasmic membrane cause leakage of intracellular material and cell metabolic disorders [40].

\section{CONCLUSION}

The phytochemical analysis of methanol extract roselle flowers confirmed the presence of 
alkaloids, saponins, steroids, triterpenoids, tannins and strong intensity of flavonoids. The results of FTIR revealed that Roselle flower extract had the main phenolic compounds. The antimicrobial assay found that the roselle flower extract had antibacterial activities against $A$. hydrophila. The antibacterial activities depended on the concentration of Roselle flower extract.

\section{REFERENCES}

[1] Cipriano, R.C. 2001. Aeromonas Hydrophila and motile Aeromonad septicemias of fish, fish disease leaflet 68. United states Department of The Interior Fish and Wildlife Service Division of Fishery Research Washington, D.C. DOI: 10.5021/ad.2011.23. S1.S25.

[2] Seshadri, R., S.W. Joseph, A.K. Chopra, J. Sha, J. Shaw, J. Graf, J.F. Heidelberg. 2006. Genome sequence of Aeromonas hydrophila ATCC 7966T: Jack of all trades. J. Bacteriol. 188(23). 8272-8282.

[3] Austin, B., C. Adams. 1996. Fish Pathogens. In: Austin, B. (Ed). The genus Aeromonas. Wiley. Singapore. 197-229.

[4] Tantu, W., R.A. Tumbol, S.N.J. Longdong. 2013. Detection of the presence Aeromonas $\mathrm{sp}$ on nile tilapia cultured in floating net cage in lake Tondano. Aquaculture. 1(3). 7480.

[5] Fullerton, M.J. Khatiwada, J.U. Johnson, S. Davis, L.L. Williams. 2011. Determination of antimicrobial activity of Sorrel (Hibiscus sabdariffa) on Esherichia coli 0157:H7 isolated from food, veterinary, and clinical samples. J. Med. Food. 14(9). 950-956.

[6] Lewis, K., F.M. Ausubel. 2006. Prospects for plant-derived antibacterials. In: Nature Biotechnology. Nature Publishing Group. 24(12). 1504-1507. DOI: 10.1038/nbt12061504.

[7] Bonjar, S. 2004. Evaluation of antibacterial properties of some medicinal plants used in Iran. J. Ethnopharmacol. 94(2-3). 301-305.

[8] De Boer, H.J., A. Kool, A. Broberg, W.R. Mziray, I. Hedberg, J.J. Levenfors. 2005. Anti-fungal and anti-bacterial activity of some herbal remedies from Tanzania. J. Ethnopharmacol. 96(3). 461-469.

[9] Islam, B., S.N. Khan, I. Haque, M. Alam, M. Mushfiq, A.U. Khan. 2008. Novel antiadherence activity of mulberry leaves: inhibition of Streptococcus mutans biofilm by 1-deoxynojirimycin isolated from Morus alba', J. Antimicrob. Chemother. 62(4). 751-
757.

[10] El Mesallamy, A.D., M. Ahmad, A.A. Souleman, A. El Morsy, A. Abd El-Naby 1. 2016. Effects of Roselle calyx (Hibiscus sabdariffa L.)-supplemented diets on growth and disease (Aeromonas hydrophila) resistance in Nile tilapia (Oreochromis niloticus L.). Egypt. Pharm. J. 15(2). 78.

[11] Chang, H.C., C.H. Peng, D.M. Yeh, E.S. Kao, C.J. Wang. 2014. Hibiscus sabdariffa extract inhibits obesity and fat accumulation, and improves liver steatosis in humans. Food Funct. 5(4). 734-739.

[12] Abdallah, E.M. 2016. Antibacterial activity of Hibiscus sabdariffa L. calyces against hospital isolates of multidrug resistant Acinetobacter baumannii. J. Acute Dis. 5(6). 512-516.

[13] Handarini, K. 2014. Potential of Rosella (Hibiscus Sabdariffa L.) flower extract as a natural colorant and preservative in jelly snacks for children. HEURISTIC J. Ind. Eng. 11(2). 32-42.

[14] Abdallah, E.M. 2016. Antibacterial efficiency of the Sudanese Roselle (Hibiscus sabdariffa L.), a famous beverage from Sudanese folk medicine. J. Intercult. Ethnopharmacol. 5(2). 186.

[15] Olaleye, M.T. 2007. Cytotoxicity and antibacterial activity of Methanolic extract of Hibiscus sabdariffa. J. Med. Plants Res. 1. 9-13.

[16] Jantrapanukorn, B., S. Pongpraritt, P. Powthong, T. Pheungphu. 2017. The study of antibacterial activity in enteric pathogens of Roselle (Hibiscus sabdariffa Linn.) by broth micro-dilution method'. J. Appl. Pharm. Sci. 7(5). 119-122.

[17] Handa, S.S., S.P.S. Khanuja, G. Longo, D. Rakesh. 2008. Extraction: technologies for medicinal and aromatic plants. International Centre for Science and High Technology. 2122.

[18] Purwakusumah, E.D., M. Rafi, U.D. Safitri, W. Nurcholis, M.A.Z. Adzkiya. 2014. Identification and authentication of Jahe Merah using combination of FTIR spectrocopy and chemometrics. Agritech. J. 34(1). 82-87.

[19] Kirby, T.W., B.R. Hindenach, R.C. Greene. 1986. Regulation of In Vivo transcription of the Escherichia coli $\mathrm{K}-12$ metJBLF gene cluster. J. Bacteriol. 165(3). 671-677.

[20] Sayed SM, A.A. 2014. Minimum inhibitory and bactericidal concentrations (MIC and 
$\mathrm{MBC}$ ) of honey and bee propolis against Multi-Drug Resistant (MDR) Staphylococcus sp. isolated from Bovine Clinical Mastitis. Altern. Integr. Med. 3(4). 171.

[21] Lestari, P.P., D. Kusrini, K. Anam. 2014. Anthocyanin identification of Methanol-HCl extract active fraction in Rosella (Hibiscus sabdariffa L.) and its potential as Xanthine Oxidase inhibitor. Jurnal Sains dan Matematika. 22(3). 72-78.

[22] Nugrahani, R., Y. Andayani, A. Hakim. 2016. Phytochemical screening of beans (Phaseolus vulgaris L) extract in powder preparation. IPA Edu. Res. J. (JPPIPA). 2(1) 8.

[23] Rohyani, I., E. Aryanti, Suripto. 2015. Phytochemical content of some of local plant species frequently used as raw materials for traditional medicine in Lombok Island. Proceeding of National Seminar of Indonesian Biodiveristy Community. 1(2). 388-391. DOI: 10.13057/ psnmbi/m010237.

[24] Sujatha, S., G. Prakash. 2013. Bioactive screening and antimicrobial activity of flowers from the selected three medicinal plants on chosen microbes. Int. J. Curr. Microbiol. Appl. Sci. 2(5). 211-221.

[25] Groppo, F., M. Pochapski, E. Fosquiera, L. Esmerino, E. dos Santos, P. Farago, F. Santos. 2011. Phytochemical screening, antioxidant, and antimicrobial activities of the crude leaves' extract from Ipomoea batatas (L.) Lam. Pharmacognosy Mag. 7(26), 165.

[26] Ardila, A., I. Chairani, N. Nurdiati, N.H. Fitriyah. 2017. Herbal nanoparticles fabrication in effervescent tablet using solvent method emulsification diffusion combination high speed homogenizer. National Seminar on Science and Technology, Faculty of Engineering, University of Muhammadiyah Jakarta. 1-2.

[27] Hastuti, N.D. 2012. Making functional drinks from honey and rosella extracts (Hibiscus sabdariffa Linn.). J. Food Tech. 3(1). 35.

[28] Irsyad, M., Mappiratu, A. Rahim. 2017. Anthocyanin production covered by maltodextrin from rosella flower petals (Hibiscus Sabdariffa, L.) and its application in functional food processing. E-Jurnal Mitra Sains. 5(1). 12-25.

[29] Hudaya, T., A. Sabianto, S. Prasetyo. 2015. Tannin removal by hot water as the pretreatment of the multi stages extraction of Phaleria macrocarpa bioactive compounds. Proceedings of the National Seminar on Chemical Engineering Development of Chemical Technology for the Processing of Indonesian Natural Resources. Yogyakarta. 1-8.

[30] Safitri, L., T. E. Susilorini, P. Surjowardojo. 2017. The evaluation of antibacterial activity (Streptococcus agalactiae) by using Mahkota Dewa extract (Phaleria macrocarpa L.) with diffirent solvent. J. Anim. Husb. Sci. Tech. 12(1). 8-15.

[31] Tiwari, P., B. Kumar, M. Kaur, G. Kaur, H. Kaur. 2011. Phytochemical screening and extraction: a review. Int. Pharm. Sci. 1(1). 98-106.

[32] Greenwood and Slack. 1995. Medical Microbiology. ELBS. Hongkong.

[33] Afolabi, O.C., F.T. Ogunsola, A.O. Coker 2008. Susceptibility of cariogenic Streptococcus mutans to extracts of Garcinia kola, Hibiscus sabdariffa, and Solanum americanum. West Afr. J. Med. 27(4). 230-233.

[34] Yin, M., C. Chao. 2008. Anti-Campylobacter, anti-aerobic, and anti-oxidative effects of roselle calyx extract and protocatechuic acid in ground beef. Int. J. Food Microbiol. 127(1). 73-77.

[35] Brooks, G.F., J. Jawetz, L. Melnick, E.A. Adelberg. 2013. Medical Microbiology, 26 ${ }^{\text {th }}$ Ed. McGraw-Hill Medical. Philadelphia.

[36] Eggensperger, H., M. Wilker. 1996. Hibiscusextrakt - Ein hautvertraglicher Wirkstoffkomplex aus AHA'a und polysacchariden. Parfumerie und Kosmetik. 9. 540-543.

[37] Cowan, M.M. 1999. Plant products as antimicrobial agents. Clin. Microbiol. Rev. 12(4). 564-582.

[38] Dzulkarnain, B., D. Sundari, A. Chozin. 1996. Antibacterial medicinal plants in Indonesia. Cermin Dunia Kedokteran. 110. 35-48.

[39] Cavalieri, S.J., R.J. Harbeck, Y.S. McCarter, J.H. Ortez, I.D. Rankin, R.L. Sautter, C.A. Spiege. 2005. Manual of antimicrobial susceptibility testing. In: Coyle, M.B. (Ed). American Society for Microbiology. University of Washington. Seattle, Washington. 241.

[40] Ayu, P., C. Devi, E. Zubaidah, F.H. Sriherfyna. 2016. Physical-chemistry characteristics and antibacterial activity of Bilimbi (Averrhoa bilimbi L.) leaves extract. Food J. Agroind. 4(1). 400-409. 